\title{
Cores of production: Reactors and radioisotopes in France
}

\author{
Matthew Adamson \\ McDaniel College, Budapest. \\ mhadamson@gmail.com
}

Dynamis

[0211-9536] 2009; 29: 261-284
Fecha de recepción: 22 de febrero de 2008

Fecha de aceptación: 27 de junio de 2008

SUMMARY: 1.- Introduction. 2.-The cyclotron, Collège de France. 3.-The experimental reactor, Zoé. 4.-The research reactor, P2. 5.-The production reactors. 6.-British reactors. 7.-Conclusion: radioisotopes, research reactors, and system orientation.

ABSTRACT: This paper concerns the technologies used in radioisotope production in the French Atomic Energy Commission (the Commissariat à l'Energie Atomique) between 1946 and 1958. Particular attention is given to the various instruments used for the bombardment of isotopes, including accelerators and reactors, and their relationship with the CEA's radioisotope preparation laboratories. Ultimately, the vast majority of bombardments took place in research reactors. These versatile machines, and the isotopes and other materials that passed through them, act as historical tracers: they shed light on the orientation of the entire atomic system in which radioisotope production is found.

PALABRAS CLAVE: Radioisótopos, investigación de reactors, Comisariado para la Energía Atómica, sistemas tecnológicos, programas atómicos.

KEY WORDS: Radioisotopes, research reactors, Commissariat à l'Energie Atomique, technological system, atomic programmes.

The Saclay pile (called P2 or EL2) will allow for the production of [radioisotopes] in quantities sufficient for all demands of a scientific, therapeutic, or industrial nature. Lew Kowarski, $1951^{1}$.

Strange pustules erode French uranium, paralyzing our 2nd atomic pile. Headline in France Dimanche, 7-13 September 1952.

1. Kowarski, Lew. Handwritten manuscript, September 1951. Niels Bohr Library, American Institute of Physics. Series IV, Box 4, Folder 3. 


\section{Introduction}

While examing the uses, users and distribution of radioisotopes, we ought to consider how and where radioisotopes are made. In a technical sense, «how» is simple: one must bombard an isotope with a nucleon and then prepare the irradiated isotope for use as an experimental or therapeutic instrument. But beginning with irradiation, the simplicity breaks down. First of all, two sorts of machines exist for this irradiation, the particle accelerator and the nuclear reactor, and these machines fall into several sub-categories, to be considered below. Moreover, beyond any question of supply and demand outside of atomic agencies, there exists within them a link between irradiation and the preparation of radioisotopes, as well as a link between the orientation of the system and the quantity and nature of radioisotopes produced. In post World War II France, the number of preparations for the delivery of radioisotopes increased along with irradiations of the same, and the overall number of radioisotopes produced and delivered by the French atomic agency, the Commissariat à l'Energie Atomique (CEA), rose with the expansion of the Commissariat's budget and resources. But not exactly. Radioisotope production required far less capital than making atomic bombs or generating electricity. Yet, despite their relatively low cost, the number of radioisotopes produced was not always proportional to the increased resources pouring into the CEA, and this variability sheds light on the orientation of the system as well as the nature of the research reactors used for the vast majority of irradiations.

As noted, the machines used to bombard isotopes changed by type: reactors replaced particle accelerators as the main platform for irradiation. And they grew more powerful: bigger reactors with higher neutron fluxes could make a wider variety of increasingly more powerful and numerous radioisotopes. It has been shown that with the resultant industrialization of radioisotope production, in France as in the US, Britain and elsewhere, the relationship between government and the various institutions using radioisotopes changed - a mark of the historical importance of this mass production $^{2}$. What, though, was the significance of this qualitative and

2. Angela Creager finds that mass-production of radioisotopes in the US greatly increased government involvement in production and distribution, and that in the US «production and circulation of these hot commodities bound together the government, industry, hospitals, 
Dynamis 2009; 29: 261-284

quantitative leap in radioisotope production within the atomic programmes themselves? Margaret Gowing and Lorna Arnold considered the problem when they examined the British atomic programme of the early 1950s:

«Radioisotopes were incidental to the main purposes of the British atomic energy project, the first and most important example of «spin-off» (...) In this grim and troubled period the radioisotope programme was, as one scientist observed, «the only blessing which has so far arisen from the development of nuclear energy - an indirect one, but in a field where blessings have been comparatively rare it should not be overlooked on that account» ${ }^{3}$.

One is reluctant to say that radioisotopes were «incidental» given that they were in the planning in Britain from 1944, that they were planned from 1946 in France, and that in the US production began as early as November 1943, a year and a half before the first atomic bombs were envailable ${ }^{4}$. However, Gowing and Arnold are perfectly right to suggest that radioisotope production was not central to the British atomic programme, as it required far fewer resources than making bombs. Nevertheless, there it was, planned for. Below, in an attempt to consider the place of radioisotope production in a nuclear complex that was geared towards making weapons, I examine the accelerators, reactors and radiochemical laboratories of the CEA from 1946 to 1958 -in what machines were isotopes bombarded, how often, and where were they sent for post-irradiation preparation? In so doing, a door opens to a larger problem: what was the orientation and nature of the Commissariat à l'Energie Atomique? Historians describing the CEA of the period have thought big: the CEA was a «nationalist technopolitical regime», an embodiment of «grand programme» scientific practice in France, «a state within a state«, and, according to the CEA itself, «a mountain of progress and innovation» ${ }^{5}$. Indeed, the CEA was in its way all of these.

and scientists». Creager, Angela. The Industrialization of Radioisotopes by the US Atomic Energy Commission. In: Grandin, Karl; Wormbs, Nina; Widmalm, Sven, eds. The Science-Industry Nexus: History, Policy, Implications. Proceedings of Nobel Symposium 123. Sagamore Beach. MA: Science History Publications; 2004, p. 141-167, 157.

3. Gowing, Margaret; Arnold, Laura. Independence and deterrence: Britain and atomic energy, 1945-1952. Volume II. New York: St. Martin's Press; 1974, p. 337-338.

4. Gowing; Arnold, n. 3, p. 316-338; Creager, n. 2, p. 146.

5. («Nationalist technopolitical regime») Hecht, Gabrielle. The radiance of France: Nuclear power and national identity after World War II. Cambridge, Mass.: MIT Press; 1998. («Grand programme») Jacq, François. Practiques scientifiques, formes d'organisation et représentations de la science 
This is because, technologically-speaking, the CEA was above all else a reactor-building institution, and its reactors were finely suited to do and make a number of things. As reactors came on line, this left a lot of space for radioisotopes; but still, space was limited.

\section{The cyclotron, Collège de France}

CEA radioisotope production did not begin with a reactor, or even in the CEA proper. The CEA was founded in 1945 and began to assemble itself in 1946; for radioisotopes, it depended on CEA High Commissiona Frédéric Joliot's cyclotron, finished in 1940 in the basement of the Collège de France. Like all cyclotrons, the Collège de France machine could only produce radioisotopes slowly and at considerable expense, as Ernest Lawrence discovered in the 1930s when he used a cyclotron to make radioisotopes for hospitals and scientific laboratories ${ }^{6}$. During the war, Joliot used the radioisotope output of his cyclotron as well as that of a Van de Graaff accelerator in his laboratory in the Paris suburbs to trace biological and chemical processes ${ }^{7}$. The work was characteristic of cyclotron use elsewhere. As in the United States (Berkeley, St Louis, etc.) and Britain (Cambridge and Liverpool), radioisotope-producing cyclotrons were found at universities. And research with these radioisotopes had to be undertaken nearby; their short half-lives rendered them useless if transport

dans la France de l'après-guerre: la «politique de la science» comme enoncé collectif (19441962) [PhD dissertation]. Ecole Normale Supérieure des Mines; 1996. («A state within a state») Bendjebbar, André. La bombe atomique et deux républiques, 1939-1969 [PhD dissertation]. Institut d'Etudes Politiques; 2000. («A mountain of progress and innovation»). Dautray, Robert. Une oeuvre scientifique. Les défis du CEA. n. 41. September-October 1995. p. 11.

6. By running his 37-inch cyclotron for a day and a night, Lawrence could manage but one clinical dose of $P_{32}$. Even the smallest experimental reactors could produce $P_{32}$ in quantities of an order of magnitude greater, while being put to use for other tasks besides. Heilbron, J.L.; Seidel, Robert W. Lawrence and his Laboratory: A history of the Lawrence Berkeley laboratory. Berkeley: University of California Press; 1989, p. 279.

7. Pinault, Michel. Frédéric Joliot-Curie. Paris: Editions Odile Jacob; 2000. See especially chapter XIII «Travailler sous l'occupation: chercheurs, universitaires et industriels». Weart, Spencer R. Scientists in power. Cambridge, Mass.: Harvard University Press; 1979, p. 156-162. See also Joliot-Curie, Fréderic; Joliot-Curie, Irène. Oeuvres scientifiques complètes. Paris: Presses Universitaires de France; 1961. 
was too time-consuming. Joliot hardly travelled at all: he collaborated on biomedical experiments with researchers in Paris ${ }^{8}$.

The CEA's first radioisotopes came from Joliot's machine. Among the lab's top scientists was Pierre Süe, who medical researcher Maurice Tubiana called «a remarkable chemist, a virtuoso at rapid synthesis for introducing a short-lived radioelement into a complex molecule». «Rapid» was a necessity: "[Y] ou must remember that in this period, 1946 to 1949, we had radioelements of only very short [half-lives], not exceeding some thirty minutes, all of which were made either from radium-beryllium sources or with the old, sputtering cyclotron at the Collège» ${ }^{9}$. Researchers in France like Tubiana faced serious material difficulties; it was virtually impossible to find «radioelements with medium or long half-lives (iodine131, phosphorous-32, iron-59) (...) indispensable for biological and medical research». Here the cyclotron could help, as it provided a supply of 8-day iodine $^{131}$, however meagre ${ }^{10}$.

In 1947, Joliot's cyclotron functioned sixteen hours a day. Joliot and the CEA Scientific Committee were delighted and wondered what CEA researchers could do with the cyclotron's output of radioisotopes - at which point they faced its limits square on. Only two or three research teams could scrape by with such a low yield. All the worse, even if they managed to produce radioisotopes, the CEA did not yet have adequate facilities to house more biology and biomedical research teams. The Scientific Committee agreed that they must first complete a permanent atomic research centre, then build a cyclotron and reactor on its premises ${ }^{11}$.

8. During the war, Joliot also attempted to start a corporation, SEDARS, the «Syndicat pour l'étude et le développement des applications des radioéléments sythétiques». In a letter to the director of the Institut Pasteur, he envisioned what it would do: «Presently I am having carried out the construction by industry of two large cyclotrons and I am proceeding to train technicians. A laboratory is planned where researchers, in particular biologists, will study how to properly manipulate and measure these new radioactive substances and to use them in their own laboratories». Pinault, Michel. Aux débuts de la «Big Science». La création et l'essor des laboratoires des Joliot-Curie. In: Pinault, Michel, ed. Doisneau chez les Joliot-Curie: Un photographe au pays des physiciens. Paris: Musée des Arts et Métiers/Sommières: Romain Pages Editions; 2005, p. 12-27, 23.

9. Tubiana, Maurice. Témoignage sur Frédéric Joliot-Curie. In: Bordry, Monique; Radvanyi, Pierre, eds. Oeuvre et engagement de Frédéric Joliot-Curie. Les Ulis: EDP Sciences; 2001, p. 60-63, 61.

10. Tubiana, n. 9, p. 61.

11. Procès-Verbal du Comité Scientifique, March 4, 1947. Commissariat à l'Energie Atomique. This cyclotron, the Saclay cyclotron, was finished in 1954. 
While cyclotrons were radioisotope producers, few would have called them efficient. Nevertheless, the perceived versatility and usefulness that radioisotope production lent to cyclotrons and other particle accelerators never disappeared. In 1952, High Commissioner Francis Perrin seized upon it. When industry-minded Administrator General Pierre Guillaumat questioned the CEA's need to commit funds to what would become the Saclay synchrotron, Perrin found three strategies to defend his case. The synchrotron would be assembled in part by private industry, Guillaumat's preferred method; only with it could France train physicists to work at CERN; and the synchrotron, like the cyclotrons before it, had «its usefulness (...) in particular the making of certain artificial radioelements». Even after CEA particle accelerators had lost their relevance as radioisotope producers, Perrin could still present them as such. Guillaumat agreed to launch a formal study for the accelerator programme ${ }^{12}$.

\section{The experimental reactor, Zoé}

In the CEA, reactors came to supersede particle accelerators as platforms for radioisotope production, and histories of the CEA have usually treated those reactors as important, if not with reverence. Scholars of the French atomic bomb have been particularly interested in how and when plutonium production reactors appeared. In such cases, reactors are treated in context, their origins as written into the CEA's first long-term industrial plan, which itself is added to the list of developments having some bearing on the more pressing problem of the politics behind the bomb ${ }^{13}$. Reactors have also appeared as a nexus of scientific interests and practices; naturally, around reactors of any size, groups of engineers and scientists must collect and interact, and their exact organization within the larger CEA to some extent demonstrates the nature of the whole ${ }^{14}$. They also appear as symbolic and instrumental incarnations of atomic policy; reactor design, and the

12. Procès-Verbal du Comité de l'Energie Atomique, November 6, 1952. Commissariat à l'Energie Atomique.

13. Mongin, Dominique. La bombe atomique française, 1945-1958. Brussels: Bruylant; Paris: LGDJ; 1997. Pô, Jean-Damien. Les moyens de la puissance: les activités militaires du CEA (19452000). Paris: Ellipses; 2001; Scheinman, Lawrence. Atomic Energy Policy in France under the Fourth Republic. Princeton: Princeton University Press; 1965.

14. Jacq, n. 5 . 
Dynamis 2009; 29: 261-284

reactor's consequent capabilities, affects policy-implementation as well as policy-making at the highest level ${ }^{15}$.

Yet, oddly, in the case of the relationship between reactors and radioisotopes, in-house celebratory publications that might ring most hollow reveal the most. Why? In the case of radioisotope production, all of the reactors within an atomic programme matter, because radioisotopes are relatively cheap and easy to make, and, if suitably adapted, any reactor can be used to bombard them with neutrons. Until the beginning of the 1960s all of the CEA's reactors, even its plutonium production reactors, were put to such use. Thus, CEA-produced accounts describing the CEA's advance from one reactor to the next can provide quite useful information as to how and why radioisotope production increased over the years.

The CEA was never shy about celebrating its first reactor (and is still celebrating it); before it, despite moving its administration into a wellappointed headquarters and despite the development of a research facility at the unused fort of Châtillon in the suburbs of Paris, the CEA found itself taking cover from criticism. As of the summer of 1947, it had produced next to nothing, at least nothing obvious to the public and body politic. This led to an especially difficult state of affairs, when 1947's severe inflation could be contrasted to the CEA's substantial budget ${ }^{16}$. The CEA's Scientific Committee had expected to finish the first French reactor by the end of that year ${ }^{17}$. However, the hiring of competent scientists and engineers proceeded

15. Hecht, Gabrielle. The Radiance of France. Cambridge: MIT Press; 1998. See Chapter two.

16. In July 1947 the Scientific Committee believed that «the time has come for the high commissioner to hold a press conference» to follow a plenary session with Prime Minister Paul Ramadier (Procès-Verbal du Comité Scientifique, July 8, 1947. Commissariat à l'Energie Atomique). After encountering unexpected criticism at the conference, the Committee decided not to hold another until they could present the world with a concrete achievement. For these first years of the CEA see Weart, n. 7. Goldschmidt, Bertrand. L'Aventure atomique. Paris: Fayard; 1962; Goldschmidt, Bertrand. Les rivalités atomiques 1939-1966. Paris: Fayard; 1967 [translated by Georges Temmer as Atomic Rivals. New Brunswick: Rutgers University Press; 1990]. For an account centered around the figure of Frédéric Joliot, see Pinault, n. 7.

17. And they suffered from no shortage of ideas as to what to do with it. Their expectations took several forms. The Scientific Committee planned for biological and medical services. The military representative of the CEA steering committee asked for radioisotopes in order to study «lesions caused by radio-active elements». Lew Kowarski wondered whether a «Comité National Français» would not be necessary to oversee radioisotope distribution, while Jules Guéron foresaw a need for national legislation. For biological and medical services see Procès Verbal du Comité Scientifique, September 9, 1946, January 27, 1947, and June 10, 1947. For the Army's request for radioisotopes, see Procès-Verbal du Comité Scientifique, January 27, 
slowly, and production of pure uranium proved elusive. That summer, the CEA Scientific Committee became convinced that any reactor, no matter what its fuel or power, would be of benefit, as it would demonstrate the ability of the French programme to construct substantial nuclear apparatus. The CEA had $\mathrm{UO}_{2}$, heavy water and personnel on hand, and any question as to whether to do this quickly became rhetorical.

The result was Zoé ${ }^{18}$, an experimental reactor. It was 'experimental' for two reasons. First and most obviously, within Zoés core France initiated its first chain reaction-an experiment of sorts which France completed on December 15, 1948. Second, experimental reactor here indicates size. First reactors in other countries, such as CP-1 in the United States, F1 in Russia and ZEEP in Canada, tended to be simple, low-power devices. Its place in the sequence of French reactors and simple design served to designate Zoé as experimental as well, and to differentiate it from France's reactors to follow.

Zoé the reactor and the CEA cyclotron were different by definition and by nuance. The task of assembling Zoé involved more distinct teams of specialists: physicists to plot design, chemists to assure the purity of its materials, electricians to arrange its control and safety systems, and engineers and technicians to construct the superstructure and mechanisms. In addition, greater amounts of exotic materials like uranium oxide and heavy water went into Zoé. Yet there were similarities as well. Both Zoé and the cyclotron required a substantial crew to operate them. Both released high-energy nuclear particles to bombard targets -in the cyclotron by placing the target before a particle beam, in the reactor by placing the target amidst a swarm of neutrons.

A one-dimensional beam versus neutrons in a three-dimensional space: this difference was of particular importance. Both cyclotrons and reactors were multiple-use machines. Besides making radioisotopes, cyclotrons could be used to induce fission or to otherwise crash one particle into another for the purposes of experiment. But they could be used for only

1947. For national committee and legislation, see Procès-Verbal du Comité Scientifique, March 4, 1947. Commissariat à l'Energie Atomique.

18. Lew Kowarski's invention: Zero energy, uranium Oxide, Eau lourde. He flirted with the acronym FLOP (French Low Output Pile) until Joliot learned that it was the English equivalent of four, a theatrical fiasco. As for the other French reactors of our period, P2's («pile 2») designation later became EL2 («eau lourde 2»), and Zoé's became, officially, EL1. G1, G2 and G3 gained their designations from their moderator, graphite. 
one such task at a time. Even low-power experimental reactors such as Zoé were importantly different. Activities could coincide. Isotopes might be put in the core of Zoé while counters were calibrated, control and safety mechanisms were tested, materials for next-generation reactors were subjected to heat and radiation, or any number of experiments were carried out in one of Zoé's several experimental channels. The last is crucial: there was room in the core of even the smallest reactor for several objects, isotopes being but one sort. So, excepting shutdown of the reactor itself (necessary to remove radioisotopes in the first place), radioisotope production from a reactor was steady, as opposed to a cyclotron's intermittent output.

Zoé's schedule during the summer of 1949 became typical: mornings were reserved for neutron flux measurements and graphite purity tests, afternoons for various experiments and particle detector calibrations, and evenings - the night shift- for radioisotope production ${ }^{19}$. An initial batch of those radioisotopes included phosphorous-32, sulfur-35, calcium45 and iodine-131. Zoé advanced France to self-sufficiency in relatively weak variations of sodium-24, bromide- 80 and arsenic-76. Lew Kowarski, the CEA's Director of Scientific Services, noted that by 1950 deliveries of radioisotopes issuing from Zoé totalled about 100 per month. By March 1952, the CEA had made 2,916 deliveries ${ }^{20}$. Zoé's neutrons boosted the half-lives of the types of radioisotopes that the cyclotron already produced, and made new radioisotopes.

Longer half-lives; more sorts of radioisotopes; and more of them. Users of radioisotopes in France multiplied thanks to all three factors. Greater availability was, of course, the principle reason. So too were longer half-lives: compared to one from a cyclotron, a radioisotope from an experimental reactor could be transported considerably farther away before it was no longer useful ${ }^{21}$. In addition, Zoé's steady output gave the CEA's Section des

19. Comptes Rendus du Sous Comité de la Pile de Châtillon, May 201949 and July 22, 1949. Commissariat à l'Energie Atomique. M6/14.22 (1) 76-879 HC.

20. Kowarski, Lew. Le progrès de l'énergie nucléaire en France. Fourth World Power Conference, London; 1950. Commissariat à I'Energie Atomique. DRI F4/22 78\&79. Goldschmidt, Bertrand. La consommation des radioéléments artifiels en France d'Octobre 1949 à Avril 1952. Commissariat à l'Energie Atomique. Fonds Toutée-Vergne, 85 H3.

21. One might imagine a circle radiating out from Collège de France or Châtillon. From the Collège cyclotron the circle reached into the Parisian suburbs; from Châtillon, it reached into Belgium. And users abounded: various academic institutions in Paris; government agencies such as 
Radioéléments its first chance to hone techniques for separating radioisotopes. Before Zoé, the Section had found itself without enough material to learn how to prepare various radioisotopes, much less manufacture them in number. With the reactor, the Section became a viable unit in the CEA, including by 1952 seven engineers and eight technicians, led by Section Head Charlie Fisher ${ }^{22}$. Unfortunately, the Section found itself unable to study techniques for certain radioisotopes, including highly-irradiated samples of phosphorous, iodine, cobalt and iron; France imported those from Britain.

Here then was the catch, Zoé's limit. Imports from Britain increased in rhythm with the French reactor's output. The CEA made approximately 300 deliveries of radioisotopes in 1949 and 1,000 the following year. 1951 was the year of sustained radioisotope manufacture, revealing what sort of production Zoé alone could maintain: 1,431 deliveries. These deliveries must be measured against imports, almost all coming from Britain: while no clear measure can be obtained for 1949, Britain made approximately 500 deliveries in 1950 and approximately 700 in 1951. Clearly, if demand continued to increase, then imports had to rise with it. Even after upgrade, Zoé could not cover the gap. In 1952 Zoé underwent a partial reconstruction -replacement of uranium oxide with natural uranium and the addition of a cooling unit to its heavy water pump system. It could now run continuously at 150 kilowatts. This intensified its neutron flux by an order of magnitude, but given that Zoé had begun life as a zero-power reactor, this meant little in terms of radioisotope production. Gains were marginal; radioisotope deliveries coming from Zoé increased by a few hundred at best, no different from earlier increases.

the Ministry of Education, the Inspection des Subsistances, and the Laboratoire Central de l'Armement; private industries including steel makers, engineering firms, heavy machinery manufacturers and petroleum refineries; the nationalized gas and electric industries; French and foreign hospitals; and, of course, the CEA itself. In addition, the CEA actively encouraged and aided several of these agencies to exploit radioisotopes. See Emplois non médicaux des radioéléments, May 28, 1950. Archives Nationales, 307AP 223. See also Guéron, Jules. Some industrial applications of radioelements made at the Commissariat à l'Energie Atomique. Rapport CEA no. 122, 1952 (paper presented at the Radioisotopes Techniques Conference, Oxford, England, July 19, 1951). Commissariat à I'Energie Atomique. For a description of the first uses to which Zoé was put, see also Ertaud, André. Utilisation et fonctionnement de la pile de Châtillon. Atomes. 1949; 35: 50-51.

22. Goldschmidt, n. 16, p. 2. 


\section{The research reactor, P2}

France completed its second reactor in October 1952. Lew Kowarski named it P2 («Pile 2»), an apt designation, as cold as 'Zoé' was warm; the name indicates the primary difference between it and Zoé, one which was historical. It had a precedent in the form of Zoé (later in the 1950s to become «EL1» to P2's «L2»). Precedent meant crews experienced in reactor construction and operation ${ }^{23}$; and it meant a Section des Radioéléments practiced in preparing irradiated isotopes for practical use and shipment. P2's output of radioisotopes could easily be integrated into the CEA's radioisotope production system.

As a machine, P2 most differed from Zoé in its complexity. Kowarski called Zoé «a fundamentally easy thing to build», uranium oxide dipped into a tub filled with heavy water ${ }^{24}$. Here the Director of Scientific Services disregarded (one senses on purpose) the nascent technological system required to build such a machine, but, as far as the design and function of Zoé were concerned, Kowarski spoke accurately. P2 was more powerful and complex. Like Zoé, P2 dipped uranium into heavy water, but otherwise it broke new ground. It included aluminum-clad natural uranium rods (as opposed to Zoés uranium oxide ones) loaded into 135 tubes. In addition, the Scientific Committee planned for a cooling system circulating compressed $\mathrm{CO}_{2}$ gas around P2's core, a coolant unprecedented in the atomic world. In its final form, $\mathrm{P} 2$ included nineteen horizontal channels for irradiation and flux measurements, eight vertical channels ${ }^{25}$, and a thermal column.

23. As early as 1950, almost two years before P2 went critical, Kowarski could tell an international audience that «the number of technicians who are familiar with the operations of the Châtillon pile and are capable of watching over it has grown (at the beginning of 1950) to about twenty; half a dozen engineers are able to work out and devise new types of reactors, and, when needed, to find new solutions». Kowarski, n. 20.

24. Kowarski, Lew. Interview with Charles Weiner, 1969. p. 183. American Institute of Physics.

25. In addition, apparently at the insistence of Irène Joliot-Curie, there were 35 small vertical channels, designated «for chemists». They were positioned in between the vertical fuel elements («not very convenient» remembers Jacques Bernot), above the core, outside of any intense flux of neutrons. They went largely unused. Bernot, Jacques. Interview, 31 October 2005. Historique sur la construction et l'utilisation d'EL2 (Juin 1949-Janvier 1960). Commissariat à l'Energie Atomique. Service des Grandes Piles de Saclay, HC F6/23.30. (Hereafter referred to as Historique I). For the best description, see: IAEA Directory of Nuclear Reactors. Vols I-IV. Vienna; 1960, 1962, p. 269-273. 
This greatly augmented the CEA's volume of irradiation space, in a core of much higher neutron flux.

It entailed a shift in quantity and quality of radioisotopes. The difference was not so dramatic as that between Zoé and the cyclotron; it was one of degree, not type. Nevertheless, that degree was important. Whereas at best Zoé could produce isotopes for a yearly total of 1,431 deliveries (1951), P2 could make for 3,600 deliveries (1956; this includes a handful deliveries from Zoé, used at that point for training and materials testing, and a few deliveries from $\mathrm{G1}$, about which below) ${ }^{26}$.

As a site, and sight, of production, P2 differed very little from its predecessor. A visitor in its warehouse-like housing would see a large steelframed concrete block, railing atop, the covers of experimental channels appearing regularly upon the sides of its radiation-protective shield and scattered electrical equipment surrounding it. This was hardly different from Zoé; from the outside P2 was merely a bigger concrete cube. The persistent observer, however, would count more experimental channels. Of course, he or she could not see the aluminium-clad uranium metal inside P2; but he could not fail to notice the cylindrical metal uptake for P2's coolant and perceive P2's greater heat output and power.

In effect, it was the uptake that led to technical troubles unknown with Zoé. As noted, P2's cooling system was unprecedented, and, as it turned out, not an easy one to master. (Even before its start-up, P2 encountered halting technical difficulties ${ }^{27}$. Kowarski claimed to have told a journalist, "If the reactor works as predicted, then this experiment will have been superfluous» ${ }^{28}$. If so, he was not disappointed.) Advancing cautiously, P2's operators employed nitrogen before attempting to use $\mathrm{CO}_{2}$, preparing the pile to function at full power. On March 4, 1953, as they eased it

26. Statistics for annual deliveries and imports are taken from the corresponding CEA Annual Reports. Figures for deliveries and imports are combined in the 1955 Annual Report; deliveries alone for previous years are summarized in the 1960 Annual Report. Thus imports have been estimated by calculating radioisotopes unaccounted for in the 1960 Annual Report. Data for deliveries in 1956 is recorded in the 1957 Annual Report. I could find no reliable data for imports following 1957.

27. Blisters appeared on the uranium metal rods, delaying completion by two months. See Historique I, n. 25. See also, Historique EL2, 1966, p. 16. Commissariat à l'Energie Atomique. EL2/Zoé/Triton 5/6. (Hereafter referred to as Historique II). See as well Etranges postules rongent I'uranium français, paralysant notre 2ème pile atomique. France Dimanche. 7-13 September 1952; (315): 9; and Kowarski, Lew. La pile de Saclay. Atomes. 1954 May; 13-17.

28. Kowarski, Lew. Zoé: le départ des piles françaises. Echos du CEA. 1965; (2): 23. 
over 1,000 kilowatts, disaster struck. Increasing reactivity in P2's core generated increasing heat, which in turn required increased circulation of the nitrogen coolant. The system could not stand the strain. Vibrations in the coolant tubing shook and crimped the tube walls. Radiation from the core streamed into the cooling system as compressed gas diffused the opposite direction into the core. Only quick opening of a hydraulic safety valve prevented the nitrogen from completely fouling the heavy water moderator. The cooling system was moderately contaminated with radiation and inside the core the fuel elements were damaged. When Zoé experienced breakdown, the repairs required days, but with P2, the repairs took months, and it was only in January 1954 that it surpassed 1,000 kilowatts with nitrogen coolant ${ }^{29}$.

These were the travails of P2; but the most crucial development in the CEA during the years between the completion of Zoé and P2 lay outside physical construction. Frédéric Joliot was dismissed from the post of high commissioner in April 1950; Administrator General Raoul Dautry died in August 1951; at that moment, Félix Gaillard, the state secretary charged with atomic affairs, inspired by visions of atomic technologies boosting France's power and prestige, emerged to insist that the CEA steering committee design a long-term plan for expansion of CEA mining, research and production. An advisory committee proposed several courses of action, including mass production of plutonium with graphite-moderated piles capable of little else. Such reactors had been built elsewhere, and in the face of various arguments, Gaillard was inclined to choose the most certain option. All along plutonium production was discussed as a means of manufacturing fuel for future secondary reactors, and despite the sole use to which plutonium had been put, this did not change after the committee named plutonium production the principle goal of the CEA's first Five-Year Plan. The draft of that Plan announced this to the French Parliament. The idea that P2 could be expected to fulfil France's radioisotope needs had in fact been circulated since the Joliot days; the Five-Year Plan, calling for reactors for plutonium production before research reactors for isotope

29. Historique I, n. 25, p. 17. Historique II, n. 27, p. 23. For Zoé see «Rapport d'avarie», September 29, 1949. Commissariat à l'Energie Atomique. Archives Zoé, B838. 
irradiations, left P2 as France's best machine for home-grown radioisotopes for the near future ${ }^{30}$.

Thus the CEA's deliveries of isotopes followed P2's performance. As noted, deliveries exclusively from Zoé plateaued in 1951 at 1,431; in 1952 the total number of deliveries actually dropped to 1,244, as Zoé was under reconstruction and P2 was late coming on line. The year 1953 exemplifies the deleterious effect that P2's breakdown had on the production of radioisotopes. In a year when deliveries should have jumped due to the powerful new reactor, they rose only slightly, to approximately 1,500. The CEA was back where it had started, relying on Zoé. Only at the end of the year was P2 ready for its first loading tray to be put into service ${ }^{31}$. Much as they had in 1951, deliveries of radioisotopes again plateaued in 1956 and 1957, at 3,600 and then 3,740 deliveries. All the while imports crept down from a peak of 1,250 in 1953 to approximately 700 in 1957.

P2 was used to do more than just bombard isotopes. Versatility is the principle characteristic of any research reactor; in its first five years of operation, P2 was used to bombard uranium for the creation of several hundred grams of plutonium; it was used to calibrate instruments and provide neutrons for experiments, including experiments involving study of P2's own neutron flux; it was used to test materials for reactors to come; it was used to study the Wigner effect; and, of course, it was a test bed for the compressed $\mathrm{CO}_{2}$ cooling system to be used in the CEA's future industrial-scale reactors. At the beginning of 1954 High Commissioner Francis Perrin spelled out P2's operational priorities: «continuous operations for accumulating $250 \mathrm{gm}$. of $\mathrm{Pu}$ »; «regular production of radioisotopes«, «detection of leaks in slugs»; «studies in support of G1» ${ }^{32}$.

Locally, production of radioisotopes gained priority. Customarily, the Section des Radioéléments placed orders: all of the horizontal channels

30. As reported in the official documentation in the parliament: «[T] he Saclay pile [Saclay was the CEA's second research facility] will permit more advanced studies (...) and will free France for good from its dependence on foreign countries for the production of radio-elements indispensable in biology, medical therapy, and even industry». Rapport fait au nom de la commission des finances sur le projet de loi de programme (no. 3759) pour la réalisation du plan de développement de l'énergie atomique (1952-1957), annexe au procès-verbal de la séance du 26 juin 1952. Journal Officiel.

31. Historique I, n. 25, p. 18.

32. G1 was the CEA's first industrial plutonium-production reactor. See below. Historique II, n. 27, p. 30. 
on P2's southern face were reserved for isotope irradiation, and a given isotope was to be placed in a specified part of P2's neutron flux. On Sunday nights the Service de la Pile halted P2's chain reaction; irradiated isotopes were unloaded early Monday morning, set on trucks and delivered to the Section's laboratory.

But radioisotopes were not the CEA's primary concern; plutonium was. In one of the CEA histories of P2 («Historique II» here), the number of isotopes irradiated in P2 goes unmentioned, while the number of grams of plutonium coming from irradiated uranium slugs is recorded (as well as the number of grams hoped for but unextracted). Some of these slugs were treated in the CEA; others were sent to the British complex at Windscale for recovery of the plutonium product. By the end of 1960, P2 had made almost 1,500 grams of plutonium (most of it passing through the British as opposed to the French processing system), useful indeed for preparations to separate and purify plutonium on an industrial scale ${ }^{33}$.

Even the progress of the Section des Radioéléments could be framed in terms of plutonium production. Meeting minutes from December 1953 record a revealing exchange. High Commissioner Francis Perrin: «[T]he production of radioisotopes will be greater with two piles [Zoé and P2] in operation. There would be reason to reinforce the team handling radioisotopes». The reaction of the director of the Department of Chemistry, Bertrand Goldschmidt: «M. Goldschmidt believes that the group preparing radioisotopes might serve as future plutonium technicians» ${ }^{34}$. There are at least two possible interpretations of this. No doubt the Section des Radioéléments could have used additional personnel, Perrin's point. At the same time, at the end of 1953 Goldschmidt's division encompassed both radioisotope and plutonium production. He might have seen himself fulfilling the CEA's call for plutonium as best he could; or, more cynically, he might have thought a reference to plutonium would more likely allow him to bring more personnel to the Section des Radioéléments. Either case proves the point: at that moment, plutonium had priority in the CEA.

Yet the precedence given to plutonium found in the CEA histories should be seen as indicating the versatility of the P2 more than signifying

33. Historique I, n. 25, p. 32-33.

34. Compte-Rendu de la Réunion des Directeurs Scientifiques et Chefs de Départements, Dec 1, 1953. Commissariat à l'Energie Atomique. Boîte F4/20.22 65-40 (HC) Programme des services 1953-1954. 
radioisotopes lost to plutonium. As we have seen, radioisotope production was planned for and carried out. Of course, underneath the surface of this history lies a crucial development. The CEA's overall focus was on plutonium production. Resources went first to the plutonium production reactors at Marcoule. No research reactor joined P2 at Saclay until EL3 came on line in July 1957 (and it was not operated at full power until April 1958). Thus, outside of Zoé's small output and the graphite reactors' production of certain high-energy radioisotopes, P2 was France's only radioisotope-producing reactor. Many individuals and groups in France were counting on P2 to boost radioisotope production. P2's breakdowns left them disappointed and reliant on British reactors if they wished to advance their techniques.

\section{The production reactors}

Zoé, the experimental reactor, brought a new mode of radioisotope production and distribution to France; P2, research reactor, was a significant, evolutionary improvement. The CEA's plutonium production reactors, G1, G2, and G2's twin, G3 ${ }^{35}$ altered the situation yet again. Their contribution was neither evolutionary nor revolutionary.

The CEA's industrial-scale reactors were not as versatile as their predecessors. Their designers planned few experimental channels, and none in the core's highest flux; the arrangement of uranium fuel elements suited other tasks. Horizontal channels filled with uranium, arranged in a lattice and surrounded by graphite, opened for insertion of new slugs and disposal of others that were already sufficiently irradiated (G1 had to be shut down for removal and loading; G2 and G3, whose channels were open at both ends, could be loaded and unloaded while in operation). Unlike Zoé and P2, cores could not be reached from channels on all four sides, much less from above. G1, and especially G2 and G3, were powerful plutonium production reactors, and to a lesser but not negligible extent, electricity-

35. G1, an air-cooled, natural uranium-fueled, graphite-moderated pilot plant, produced 38 megawatts of power (and 1.7 megawatts of electricity). G2 and G3, twin compressed gascooled, natural uranium-fueled, graphite-moderated production reactors, produced 200 megawatts of energy each (and 28 megawatts of electricity each). IAEA Directory of Nuclear Reactors. Vols I-IV. Vienna; 1960, 1962, p. 145-149. 
producing machines. The CEA's directors selected a site for them on the Rhone River and found private industrial contractors to build them. G1, G2 and G3 were the centerpieces of the CEA's Five-Year Plan, its enablement and embodiment.

Perhaps this is why Maurice Pascal, director of industrial production, declined Charley Fisher's request to have isotopes irradiated in the core of G1. After all, compared to the nuclear industrial complex at Marcoule, Fisher's Section des Radioéléments was a sideshow. Pascal at first claimed that G1's neutron flux was too weak by a factor of ten to be of any use. Fisher made his case: «As concerns the making of carbon-14 and cobalt sources, it seems in our common interest to use the tubes intended for uranium rods». Fisher knew that G1's flux was well-suited for making radioisotopes, and this was Fisher's appeal, «our common interest», and with the intersession of High Commissioner Francis Perrin, it eventually worked. It took more than a year for Fisher to receive permission to use four of G1's channels to make carbon-14 and various isotopes with long half-lives, including cobalt-60. Irradiated isotopes could be removed only as G1's normal schedule of shutdowns permitted ${ }^{36}$. In the end, G1 added little to production, deliveries of radioisotopes in 1956 (approximately 3,600 ) increasing by less than two hundred in 1957-and that due mostly to the increase in P2's kilowattage. Nevertheless, the CEA's graphite reactors made the production of several sorts of isotopes and radiolabelled molecules possible: varieties of carbon-14 and cobalt- 60 sources, curium-244, iodine-125, iridium-192, plutonium-238 for pacemakers, technetium-99 and tritium ${ }^{37}$. By the end of the 1950s the French were selling certain radio-labelled molecules to American firms ${ }^{38}$.

36. Fabrication de radioéléments artificiels. (Chef du Service des Radioéléments Artificiels [Charley Fisher] s/c de M. le Directeur du Département de Chimie au Directeur de la Production Industrielle [Maurice Pascal]), February 11, 1955; Chef de Service des Radioéléments au Haut-Commissaire, March 26, 1956; Haut-Commissaire au Chef du Service des Radioéléments, June 19, 1956. Commissariat à l'Energie Atomique. HC M6/14-22 (1) 76-879 Dossier Piles de M. Yvon; G1, M6/08-60 76-861 (HC).

37. Mazzucchetti, Denis. De divergences en convergences: les cinquante premières années de Marcoule: 1955-2005. CEA; COGEMA: Romain Pages Editions; 2005, p. 89.

38. Vente de molécules marquées généralités. Commissariat à l'Energie Atomique. Boîte F3/19-36 80-1233 HC Radioéléments. 


\section{British reactors}

In 1958 the third French research reactor, an enriched uranium pool reactor called EL3, reached its design output of 15,000 kilowatts. Radioisotope production shot up: 5,997 in 1958, 7,247 in 1959, 9,962 in 1960. The CEA no longer had to import radioisotopes to satisfy French demand, and a new period of radioisotope production was entered in full.

During the previous period, when the French were dependent on P2, they found a site outside of their country for irradiations: the British research centre at Harwell. There, a succession of experimental and research reactors served up radioisotopes for both the British and the French. In fact, this represents but one example of an Anglo-French «spirit of cooperation» ${ }^{39}$. During the period of this study, the French benefited most. The British separated plutonium from uranium slugs irradiated in French reactors; they produced radioisotopes which the French either lacked the capacity to make or the ability to produce, and sent them to the Section des Radioéléments; they made thousands of deliveries to French users; and, as the French completed the design of G2 and G3, the British supplied information about the Wigner effect.

The British began radioisotope production in 1947, after the construction of their first reactor «Gleep» (100 watts in its experimental stage, upgraded to 300 watts). Veritable mass production commenced a year later with the completion of their second reactor, the graphite-moderated, air-cooled pile «Bepo», which achieved 6,500 kilowatts. The output of the latter in particular advanced the work of the Section des Radioéléments when P2 could not be kept reliably running. The Section had already set the principle in place: anticipated separation and preparation techniques could be practiced with British radioisotopes before reactors in France could provide proper, powerful radiation. Thus, expecting P2 to increase to over 2,000 kilowatts by the end of the first trimester of 1953, the Section accepted bricks of sulphur bombarded in Bepo to learn certain phosphorous-32 techniques. They expected a smooth transition: one hand-written note recorded «P32 (de Harwell $\rightarrow$ P2)». For P2, of course, little went smoothly in 1953. In April the CEA was hoping that by the following year «the great majority of artificial radioelements used in France should be prepared, distributed and if possible

39. Goldschmidt, n. 16. 
produced under our care» ${ }^{40}$. But given P2's uneven performance, nothing could be certain, and the CEA radiochemists were perhaps relieved to be able to note, «[T]he adopted system of production will be able to count continuously on a supplement coming from the Harwell Centre». During the first years of importation of radioisotopes from Harwell, personal relations were particularly important; Bertrand Goldschmidt and the director of the radioisotope division at Harwell, Henry Seligman, had worked together in Canada during the war. By the end of 1953, the French had negotiated an official agreement with Harwell ${ }^{41}$.

\section{Conclusion: radioisotopes, research reactors, and system orientation}

All devices for irradiating French isotopes - the cyclotron, experimental, research and production reactors, and the British reactors - shared one thing in common. All sent their irradiation products to the Section des Radioéléments of the CEA (the unit was raised in the hierarchy from Section to Service in 1954, notably after P2, nursed through its worst troubles, was in steady operation). All radioisotopes had to pass through it. Then again, the Section des Radioéléments had to rely on all groups irradiating isotopes.

The tenor of these relationships differed, as we have seen. Charlie Fisher had to negotiate with Maurice Pascal and rely on the authority of the high commissioner before gaining spaces in the core of the plutoniumproduction reactors. By comparison, access to free channels in P2 was not just easy, but assumed. The Section des Radioéléments was a privileged user, or, to quote P2 engineer Jacques Bernot, a «privileged client» ${ }^{42}$, - a client considered significant, as the start-up and shutdown schedule of P2 shows. The Section des Radioéléments might also have thought of themselves as a client of the British at Harwell. While work with P2 hinged on expectations

\footnotetext{
40. Programmes et services scientifiques et techniques au cours du premier semestre 1953. Commissariat à l'Energie Atomique. Programmes Généralités (1953) F4/20.22 65-40 (HC) Programme des services 1953-1954.

41. Directeur chargé du Département de Chimie au Monsieur le Haut-Commissiare, April 20, 1953. Commissariat à l'Energie Atomique. F4/20 22 65-40 (H-C) Progammes de Services 19531954.

42. Bernot, Jacques. Interview, 31 October 2005.
} 
of radioisotope production within a single technological system, work with the British depended on personal relations.

On the whole, the Section/Service des Radioéléments was a stable entity throughout our period: steady growth; a trouble-free, welcomed move from Châtillon to Saclay; a smooth transition from laboratory to pilot-plant scale operation for mass preparations; the same man in charge throughout. A fire in the administrative office in 1957 may have been the greatest disruption the Service experienced ${ }^{43}$. When it lacked powerful enough radioisotopes to prepare new handling techniques, the British reactors filled the gap. In the re-organization of the CEA in October 1959, the Department of Chemistry, in which the Service des Radioéléments had been located, was eliminated, and the Service was placed (along with most of Chemistry's units) in the Direction des Matériaux et des Combustibles Nucléaires. The greatly increased numbers of radioisotopes made possible by new machines like EL3 and the Service des Radioéléments' own multiple-building preparation facility equipped with remote-control laboratories, and the resulting expansion of production of radioisotopes, gave this organizational change - a sign of mass production- a powerful logic ${ }^{44}$.

Compared to the growth of the Section/Service des Radioéléments, there was less continuity to reactor development. To recapitulate: Zoé, first reactor, from zero power to upgraded low power (the CEA's romantic phase: at Zoés inauguration one engineer cooed «very gentle, very calm, this nice Zoé» ${ }^{45}$ ); P2, troubled from the start, a platform for experiments, instrument calibrations, irradiations and systems trials; G1, the first in a line of graphite-moderated reactors, a pilot plant for plutonium production and a site for establishing a new working relationship between the CEA and industries; G2 and G3, the most massive CEA reactors of our period, combining the graphite and core arrangement of G1 with the cooling system

43. The fire was a bane to the historian as well, as many of the Service's records were destroyed.

44. The reorganization of the Department of Chemistry in 1953 had already revealed the lines of the CEA system of production. According to the 1953 Annual Report, its two «essential» tasks were the "classic process of the uranium cycle», the preparation of uranium metal for reactors, and the «radioactive process of the uranium cycle after irradiation in the pile (extraction of plutonium and decontaminated uranium, and separation of fission products), as well as that necessary for the preparation of artificial radioelements».

45. «'Zoé' se cache derrière cette lourde porte de plomb» a dit Joliot-Curie aux journalistes. Ce Soir. 21 Dec 1948: 1. 
pioneered by P2, able to produce dozens of kilograms of plutonium as well as thirty megawatts of electricity each; EL3, P2's successor, possessing three times its predecessor's power, for years one of the foci of the Saclay complex; and the British reactors: Gleep, the first reactor, equivalent to the upgraded Zoé in power; Bepo, as powerful as P2 but more reliable; and the Windscale piles, Britain's plutonium-production reactors, capable of making sources like cobalt- 60 .

That products from all of these different machines were sent to the Service des Radioéléments indicates three things. First, as noted, for whatever differences they presented from the outside, their innermost process was the same, the neutron-initiated fission chain reaction. If an isotope could open its eyes and «see» what was happening inside any of these reactors, the view would be much the same: a world of energetic neutrons, fissioning uranium atoms and slowly accumulating fission products. Only the moderator might differ.

Second, even if radioisotopes were not at the centre of the French atomic project, they were not an unanticipated, unforeseen bonus. From 1947 at the latest, the CEA Scientific Committee had every intention of producing radioisotopes, and the CEA's first high commissioner, Frédéric Joliot, had dreamed of making radioisotopes for years; radioisotope production was given significant priority at Zoé and especially P2; arrangements were made with the British to manufacture radioisotopes «hot» enough to allow the Section des Radioéléments to advance its techniques. When the Section received its first shipment of radioisotopes, it was not only welcomed; it was expected.

Third, at their most basic, with very few exotic exceptions, all reactors are versatile slow-neutron fission machines, and virtually all of them can be used to irradiate isotopes. Experimental and research reactors are especially adaptable. Even before her upgrade, Zoé went from being a proof-of-principle experimental machine to an instrument and tool: a research reactor for physicists and chemists, a production reactor for the chemists and engineers of the Section des Radioéléments, a calibrator for the Service des Constructions Electriques, a material-testing machine for the team preparing to build $\mathrm{P} 2$, and eventually a training reactor.

In 1955, at the International Conference on the Peaceful Uses of Atomic Energy, Lew Kowarski gave his definition for «research reactor» Struggling to find a way to distinguish peaceful apparatus from others, he hints at the primacy of context: 
«A research reactor may be defined as one which has been built for the purpose of gaining information, rather than for producing useful energy or transmuted substances. The information sought may be totally extraneous to the reactor itself, or reactor technology; the reactor then serves as a tool and a source of radiations (chiefly neutrons). Or it may be used as an object of research; a line is to be drawn here between research and advanced development in the pre-production stage; some pilot versions of industrial reactors, although - strictly speaking - of mainly informative interest, are too closely connected with production programmes to be considered research reactors [his emphasis]» ${ }^{46}$.

«Some pilot versions of industrial reactors (...) of mainly informative interest»: an illustration of what Kowarski meant is found in the American wartime reactor, $\mathrm{X}-10$, a pilot-plant reactor built at the Clinton laboratories of Oak Ridge. The Smyth Report described X-10 as a «small-scale semiworks» ${ }^{47}$. The X-10 pilot reactor and a pilot separation facility paved the way for mass production of enough plutonium to manufacture two plutonium-fuelled atomic bombs per month. This scale of production commenced when the three full-scale reactors and two full-scale plutonium separation plants in Hanford came on line at the end of 1944. Up to then, if we follow Kowarski's logic, X-10 was «too closely connected with productions programmes» to be a research reactor.

This changed, although X-10's configuration remained the same. X-10 allowed for more than convenient extraction of irradiated uranium slugs. It could be used for research, one reason the University of Chicago, and

46. Kowarski, Lew. Report on Research Reactors. For the International Conference on the Peaceful Uses of Atomic Energy. July 12, 1955. Niels Bohr Library, American Institute of Physics. Additions Series II, Box 10, Folder 12.

More definitions, this time from John F. Hogerton's The Atomic Textbook (1963). Four reactor types are defined: (1) Power reactors: reactors used as energy sources for electric power generation or propulsion; (2) Production reactor: reactors used to produce fissionable materials for defense stockpiles; (3) Test reactors: reactors used to conduct tests in support of reactor development, irradiations and heat tests; (4) Research reactors: reactors used for nuclear physics (cross sections, etc.), solid state physics (neutron diffraction of crystalline structures), radiation chemistry, analytical chemistry, biology, medicine, reactor development, production of radioisotopes, student training. P2 broke down these definitions, fitting (3) test reactor, and (4) research reactor, perfectly well, and serving as a (2) production reactor of sorts until 1956, when G1 came on line. Hogerton, John F. The atomic energy textbook. New York: Reinhold Publishing Corporation; 1963, p. 473.

47. Smyth, Henry D. Atomic energy for military purposes. Princeton: Princeton University Press; 1948, p. 111. 
not $\mathrm{Du}$ Pont, was asked to operate it ${ }^{48}$. At the end of 1944 the Clinton laboratory's scientists began to take advantage of these latter capabilities, namely

«slots for indium foils to measure neutron intensity, test holes for irradiation of sample materials, two tunnels for exposing small animals to radiation [sic], a pneumatic system for very brief irradiations of small samples, three aluminium tubes for experiments with water cooling, two holes for neutron spectrometers, and two columns of graphite blocks for exposing samples to slow neutrons» ${ }^{49}$.

Immediately the reactor began irradiating isotopes. X-10, pilot-plant reactor, without alteration of its design, became a research reactor 50 .

Due to such versatility, this ability to be wheeled around and driven in another direction, research reactors can reveal the orientation of an atomic programme. They do this just as effectively as specialized industrial machines built to mass produce plutonium: an inventory of whatever passes through their cores reveals what an atomic programme is about (and can do so before the industrial-scale reactors are up and running). At the same time, despite the unique nature of the materials they use, the specialists they require, and the large complex machines that compose them, atomic programmes are not monoliths. This perhaps goes without saying: not only do they encompass sites - mines, reactors, laboratories - that differ greatly from one to the next. Even to visit only the reactors of a large programme like the CEA in the 1950s meant encountering many very different machines and facilities. The various sub-systems of production in atomic programmes, making, for example, enriched uranium, plutonium, electricity, radiation counters $^{51}$ - or radioisotopes - are linked by material and institution but are different nevertheless. As noted, assembling a system of radioisotope

\footnotetext{
48. Smyth, n. 47, p. 111.

49. Hewlett, Richard G.; Anderson, Oscar E. A history of the United States Atomic Energy Commission: The new world, 1939-1946. University Park, Pennsylvania: Pennsylvania State University Press; 1962, p. 196-197.

50. X-10 went critical in November 1943; by the end of 1944 it was used for radioisotope production. See Swords to Plowshares: A Short History of the Oak Ridge National Laboratory. U.S. Department of Energy; 1993. [accessed 5 Nov 2005]. Available at www.ornl.gov/info/swords/ swords.html..

51. The CEA's most conspicuous physical output before Zoé.
} 
production is relatively cheap ${ }^{52}$; in France, like the US and Britain, the rising tide of resources accompanying atomic industrialization lifted all ships, including such production. On the one hand, the CEA did not finish its second high-power research reactor, EL3, until 1958, a good twelve years after its foundation, while at the same time finishing pilot-plant and full-scale plutonium-production reactors. The priority given to plutonium production is clear; it is all the more so when we take into account the 1,500 grams of plutonium created inside P2. But on the other hand, the French did nurture a radioisotope production system all along, securing a supply of radioisotopes for the Section des Radioéléments to perfect techniques when French production was not enough.

As Gabrielle Hecht describes, the constraints imposed by the design of production reactors can reveal the orientation of an atomic programme. G1, G2 and G3 could all produce plutonium and electricity, but they could only make one efficiently, and this turned out, not by accident, to be the former. The versatility of research reactors points all the same to the orientation of an atomic programme. P2 could irradiate anything with equal effectiveness; its users only contraints were found in limited neutron flux, unavailable channels and limited reactor time. An inventory of what went into those channels - radioisotopes included - and the lack of a younger, more powerful sister research reactor until 1958, reveals the CEA's orientation: its commitment to bomb-grade plutonium, and its commitment to radioisotopes, pursued with less urgency, but committed to nevertheless.

52. Angela Creager notes the words of a 1947 American Atomic Energy Commission report: «The cost of producing these radioactive and non-radioactive isotopes is a very small fraction of the cost of the atomic energy programme as a whole, but the value of the benefits is incalculable». Creager, n. 2, p. 149. 